\title{
Urban modelling for seismic prone areas: the case study of Vila Franca do Campo (Azores Archipelago, Portugal)
}

\author{
V. N. Martins ${ }^{1}$, P. Cabral ${ }^{2}$, and D. Sousa e Silva ${ }^{3}$ \\ ${ }^{1}$ Centro de Estudos Sociais da Universidade dos Açores, Ponta Delgada, Portugal \\ ${ }^{2}$ Instituto Superior de Estatística e Gestão de Informação, Universidade Nova de Lisboa, Lisboa, Portugal \\ ${ }^{3}$ Núcleo de Ecologia Social do Laboratório Nacional de Engenharia Civil, Lisboa, Portugal \\ Correspondence to: V. N. Martins (vmartins@uac.pt)
}

Received: 16 June 2011 - Revised: 22 June 2012 - Accepted: 7 July 2012 - Published: 3 September 2012

\begin{abstract}
Seismic risk mitigation comprises of land-use planning policies that enable risk reduction in areas exposed to earthquakes. Thus, the assessment of land-use plans regarding urban growth in seismic prone areas is very important. This article analyses the urban expansion of Vila Franca do Campo (island of S. Miguel, Azores, Portugal) from 1994 to 2005 based on ortophotomaps interpretations and simulates a scenario of urban growth for the year 2016 with a Land-use and Cover-Change (LUCC) model (Geomod). The goal is to evaluate the potential impact of land-use plans in managing urban growth and promoting seismic risk mitigation. Results indicate that the urban expansion, between 1994 and 2005, was done according to the Municipal Master Plan (MMP) restrictions. The scenario modelled for the year 2016 is potentially stricter for urban growth because it adds to the previous plan the constraints defined by the South Coast Management Plan (SCMP) that entered into force in 2007. In both time periods, a continuing urban growth towards seismic areas was identified. The absence of seismic risk mitigation policies and measures on both plans may contribute to increase the seismic hazard exposure and vulnerability. The results of this study strongly suggest the reformulation of future land-use plans to include seismic risk mitigation goals and policies.
\end{abstract}

\section{Introduction: the theory and the aim}

Earthquakes are massive, sudden and quite unpredictable geophysical phenomena. Their location, frequency and magnitude may interfere negatively with the regular behaviour of the social, economical and political environments of the communities, societies or even countries (Oliver-Smith, 2004). The severity of disasters triggered by seismic events is the outcome of the interaction between the geophysical phenomenon and the societies, namely, their built environment characteristics (Hewitt, 1997). During the 20th century, the population growth stimulated the construction of settlements in risk areas which often adopted inadequate constructive solutions towards seismic risk, thus, contributing for an increase of the number (CRED, 2010) and severity of earthquake-triggered disasters.

Nevertheless, societies have the ability to adjust to seismic risk by adopting formal responses to the disasters (Birkmann et al., 2010), mainly found in risk mitigation policies. Risk mitigation is a coordinated strategy, based on goals, policies and measures to minimise human and material losses from natural hazards and resulting disasters, normally being planned long term (Godschalck and Brower, 1985; Dynes, 1991). The mitigation of seismic risk is normally focused on land-use planning since it is the most effective tool to implement mitigation policies (Berke and Beatley, 1992; Godschalck et al., 1998). According to UN/ISDR (2004), landuse planning allows the combination of urban areas management and their need for social, economic and environmental development, while ensuring the reduction of risk for individuals and communities.

Godschalck et al. (1998) identify the benefits of incorporating risk mitigation with land-use planning. These include: (i) raising the awareness in communities regarding exposure to natural hazards and their potential consequences; (ii) identifying the relationships and the conflicts between public interest and the proposed mitigation policies; and (iii) building 


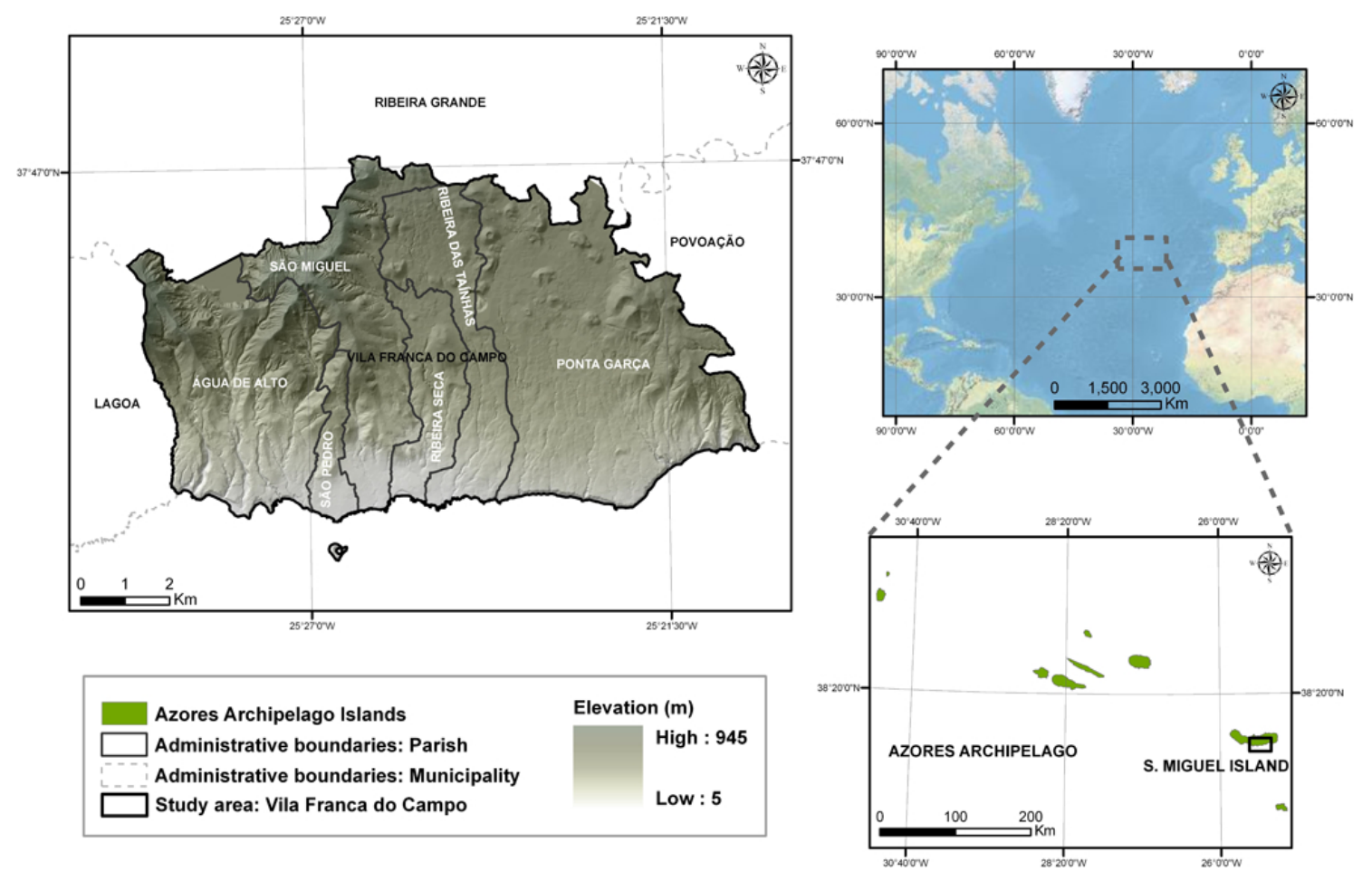

Fig. 1. The study area.

consensus among those responsible for proposing and implementing mitigation measures.

The mitigation of seismic risk through land-use planning is a multi-stage process (Berke and Beatley, 1992). Initially, it is necessary to define the extent of the problem concerning the need to introduce risk mitigation, while the second stage comprises the formulation of objectives and policies. In the third stage, planning measures are defined, according to the goals and policies outlined on the previous stage. The process is concluded with the implementation, monitoring and revision of plans that support the policies.

The success of land-use planning in seismic risk reduction depends on the type of plan being developed. Comprehensive plans are best suited to include mitigation policies, because "that plan normally already has a standing in the community as a policy guide, and the comprehensive plan encourages integration of mitigation goals and programmes with other ongoing community goals and programmes" (Godschalck et al., 1998, p. 101). Comprehensive plans comprise mitigation measures with regulatory nature, namely: building codes (e.g., Eurocode 8); zoning provision (e.g., peak ground acceleration; faults lines); regulation of urban density; and urban clustering development (Berke and Beatley, 1992). Since the land-use plans are the result and the support of the planning process, being a key step towards seismic mitigation implementation, the assessment of their impact in the urban growth on seismic areas is utterly relevant.
The adoption of the theoretical principles of Land-Use and Cover-Change models in seismically active areas is useful for three main reasons. First, it allows the analysis of LUCC by identifying the mechanisms that trigger land-use transitions and the driving forces supporting them, and also their impacts (Verburg et al., 1999). For instances, it is possible to verify if the former and/or current land-use planning policies foster sustainable urban growth by establishing an evaluation comparison between the observed land-use allocation with the restrictive regulations (Koomen et al., 2008). Second, LUCC models allow the assessing of the potential impact of land-use plans in urban growth (He et al., 2008). They make possible the identification of mitigating measures and actions within the plans, to know their regulatory or nonregulatory nature, and to measure the extent of their implementation. Third, LUCC models may support the development of future land-use plans (Verburg et al., 1999) by suggesting the incorporation of seismic risk mitigation policies.

This article aims to raise the awareness of the need to include seismic hazard mitigation policies and measures in land-use plans in earthquake prone areas. Two objectives are pursued: (i) to assess the impact of the Municipal Master Plan on urbanisation and seismic risk reduction in the municipality of Vila Franca do Campo between 1994-2005 using ortophotomaps interpretations; and (ii) to model urban growth for the year 2016, which also includes the South Coast Management Plan, to verify the possible outcomes of land-use policies. 


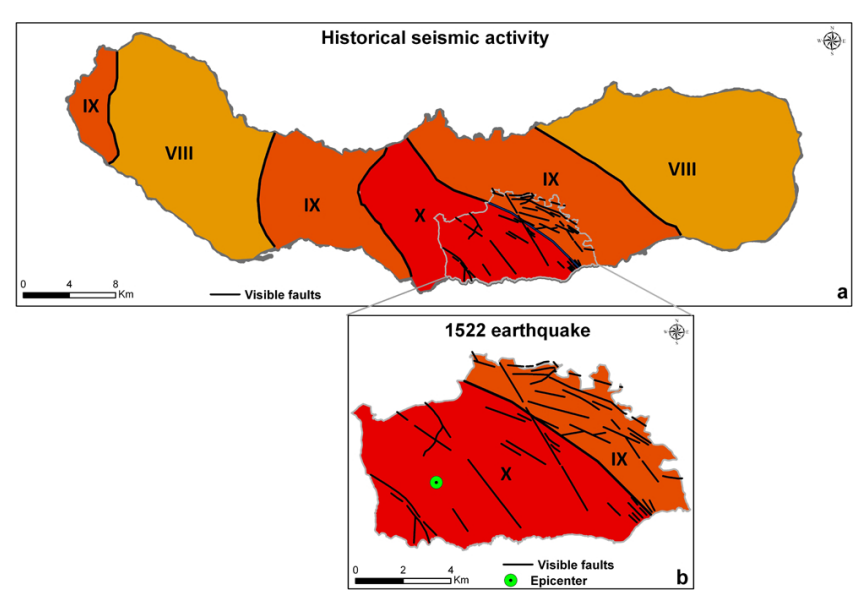

Fig. 2. Isoseismal maps representing the historical seismic activity in S. Miguel Island and Vila Franca do Campo (EMS-98). Adapted from Silveira et al. (2003). (a) illustrates the maximum historical intensity isoseismal map of S. Miguel Island (EMS-98). (b) represents the isoseismal map (EMS-98) of the 1522 earthquake and the epicentre.

\section{Study area}

The Azores archipelago is located in the North Atlantic Ocean, in the Macaronesian biogeographical region, at about $1450 \mathrm{~km}$ from mainland Portugal (Fig. 1). The archipelago is composed of nine islands of volcanic genesis, alongside a NW-SE orientation, and is divided in three groups: Eastern group (Santa Maria and S. Miguel islands); Central group (Terceira, Graciosa, S. Jorge, Pico and Faial islands); and Western group (Corvo and Flores islands). The municipality of Vila Franca do Campo, with $78 \mathrm{~km}^{2}$, is located on the southern coast of the island of S. Miguel, between parallels $37^{\circ} 42^{\prime}-37^{\circ} 47^{\prime} \mathrm{N}$ latitude and the meridian $25^{\circ} 20^{\prime}-25^{\circ} 29^{\prime} \mathrm{W}$ longitude (Fig. 1). It is divided into the parishes of Água de Alto, Ponta Garça, Ribeira das Taínhas, S. Miguel, S. Pedro and Ribeira Seca. According to the Census 2001 (SREA, 2001), the municipality had 11150 inhabitants and a population density of $143 \mathrm{inh} . / \mathrm{km}^{2}$. The parishes of S. Miguel and Ponta Garça are the most populated and the ones with a more consolidated urban area, contrasting with other parishes where linear and dispersed patterns of human occupation are predominant.

The cohabitation of Azorean population with the seismic threat dates back to the colonization during the 15th century. The location of the Azores Archipelago in the triple junction of American, Eurasian and African litospheric plates, and the presence of three main tectonic structures in the region: the Mid-Atlantic Ridge, the East Azores Fracture Zone and the Terceira Rift (Valadão et al., 2002), increases the exposure of the archipelago to the seismovolcanic episodes. Vila Franca do Campo is located on a seismogenic region dominated by the presence of regional tectonic structures with a NW-SE, NE-SW, WNW-ESSE and E-W orientation
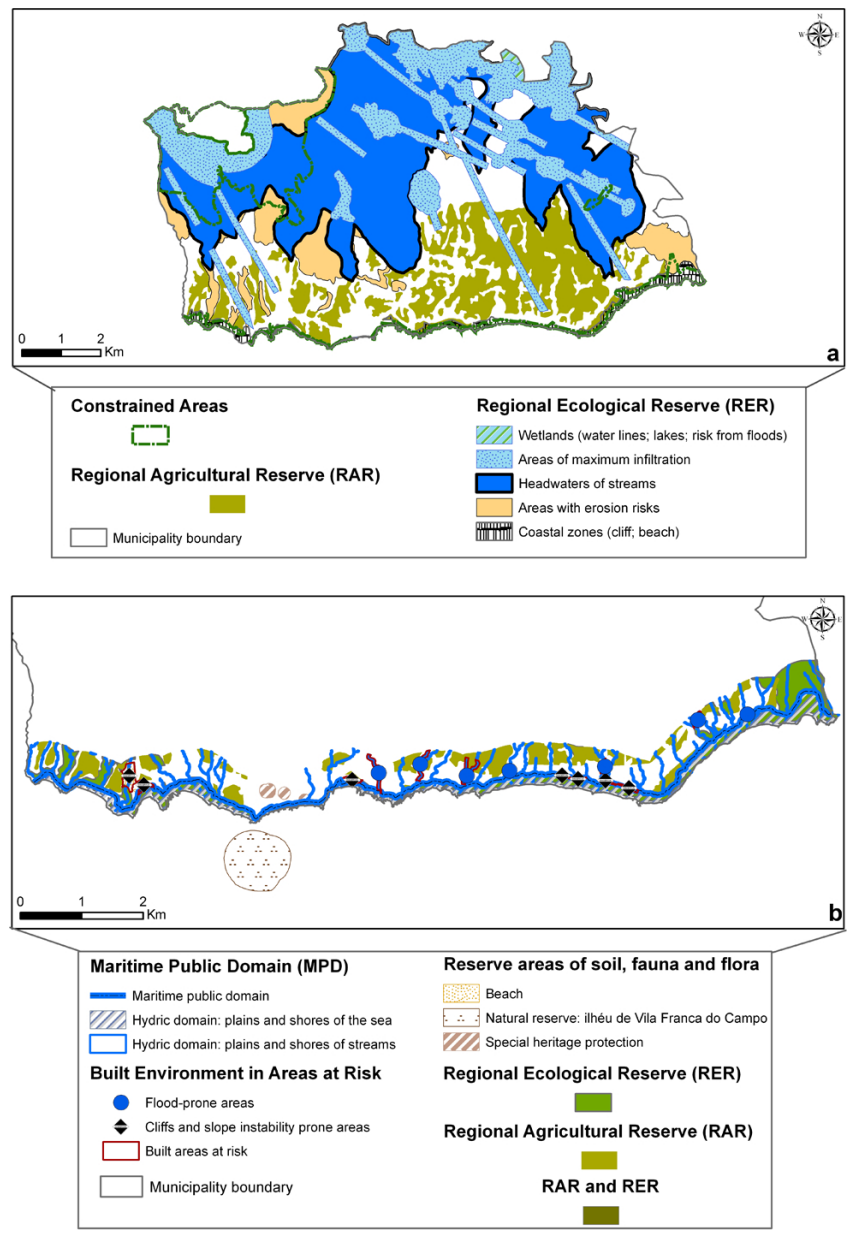

Fig. 3. Urban expansion restriction plans of MMP and SCMP.

(Gomes et al., 2005). In the map of the historical seismic activity of S. Miguel Island, the municipality is within the area limited by the IX/X-grades maximum intensity isoseismal (Fig. 2a) of the European Macroseismic Scale-1998 (EMS-98) (Silveira et al., 2003). One of the most destructive earthquakes which occurred in Azores was on the 22 October 1522, nefariously hitting Vila Franca do Campo (Fig. 2b). This earthquake triggered a landslide which caused $5000 \mathrm{ca}-$ sualties and the destruction of the settlers' houses. Since then the municipality suffered five more disastrous episodes as a consequence of the earthquakes (Table 1).

\section{Land-use planning at the local scale}

The municipality of Vila Franca do Campo is regulated by two land-use plans: the MMP and the SCMP of S. Miguel Island. The MMP was approved by the 184/1997 resolution from $02 / 10$, and it was later changed by the declarations $32 / 1997$ from 06/11, and 4/1998 from 23/03. Article 4 of the MMP considers three restrictive elements of urbanisation in the municipality: (i) Constrained Areas; (ii) Regional 
Table 1. Earthquakes occurred in the Azores Archipelago which caused human and material losses in Vila Franca do Campo (CMVFC, 1999; Silveira et al., 2003).

\begin{tabular}{|c|c|c|c|}
\hline Date & $\begin{array}{l}\text { Maximum } \\
\text { intensity (EMS-98) }\end{array}$ & $\begin{array}{l}\text { Deaths/ } \\
\text { Injury }\end{array}$ & Consequences \\
\hline 22 Oct 1522 & $\mathrm{X}$ & More than 5000 deaths & $\begin{array}{l}\text { The earthquake triggered a landslide that hit Vila Franca do } \\
\text { Campo, causing the death of its inhabitants and devastating } \\
\text { all the buildings. }\end{array}$ \\
\hline 26 Jul 1591 & VII & Many injured & $\begin{array}{l}\text { Several buildings collapsed, especially in the village of Vila } \\
\text { Franca do Campo. }\end{array}$ \\
\hline 16 Apr 1852 & VI & No casualties & Slight damages in the buildings and in the S. Pedro Church. \\
\hline 5 Aug 1932 & VI & No casualties & $\begin{array}{l}\text { Several damages in buildings in Ponta Garça (including the } \\
\text { church). Small damages in other settlements. }\end{array}$ \\
\hline 27 Apr 1935 & VI & No casualties & $\begin{array}{l}\text { Several damages in buildings, namely, in Ponta Garça and } \\
\text { Ribeira Seca. }\end{array}$ \\
\hline 26 Jun 1952 & VI-VII & Few injured & $\begin{array}{l}\text { Approximately } 331 \text { buildings destroyed in Ponta Garça. } \\
\text { Several damages in the majority of the buildings. }\end{array}$ \\
\hline
\end{tabular}

Agricultural Reserve (RAR) and (iii) Regional Ecological Reserve (RER) (Fig. 3a). Concerning seismic mitigation, two regulatory articles were identified within the MMP: (i) Article 8 , disallowing the construction of public buildings in areas of geological faults; and (ii) Article 24, preventing urbanisation inside geological fault zones (CMVFC, 1997). Nevertheless, these areas are not mapped in the MMP restriction plans. We must notice the lack of seismic mitigation regulation in the MMP and the absence of seismic hazard zonation within the plan, i.e., local peak ground acceleration maps.

The SCMP was approved by the 29/2007 resolution from $5 / 12$ and covers the $14 \mathrm{~km}$ coastline. It contains a shoreline protection area with a maximum width of $500 \mathrm{~m}$ from the coastline and a full marine protection area defined by the $-30 \mathrm{~m}$ isobaths. Article 5 of the SCMP defines four urban expansion restrictions in the area: (i) Maritime Public Domain; (ii) reserve areas of soil, fauna and flora; (iii) RAR and (iv) RER (Fig. 3b). To minimise natural risk situations, the SCMP presents a multi-hazard approach to regulate urban growth which includes a hazard zoning where "Built Environment in Areas at Risk" are identified (Fig. 3b). Articles 32 and 33 define the multi-hazard mitigatory measures to adopt in these areas, namely: urban growth restrictions, relocation and buildings rehabilitation (DROTRH/SRAM, 2007).

\section{Data and methods}

\subsection{Modelling approach}

The LUCC model was developed using IDRISI Andes software in three stages: (i) mapping of the urban areas of years 1994 and 2005 based on ortophotomaps interpretation; (ii) suitability map assessment for urban areas using Multicriteria Analysis (MCA) techniques; and, (iii) validation and simulation of an urban growth scenario for the year 2016 using Geomod. The initial stage aims to analyse the landuse allocation in the period 1994-2005 and use the resulting land-use maps as input for the simulation model. The second stage presents a heuristic suitability assessment which incorporates expert knowledge in the modelling approach, avoiding a stochastic model based on conditional probabilities that would worsen the results (Cabral, 2006). The last stage comprises urban growth modelling and validation procedures for creating an urban growth scenario for 2016 using the results from the previous stages. The different stages rationale is explained in the following subsections.

\subsection{Mapping urban areas of years 1994 and 2005}

The land-use maps were produced based on visual interpretation of ortophotomaps of years 1994 and $2005(0.5 \mathrm{~m}$ pixel resolution; $1: 5000$ scale) (SRCTE, 2010). The adopted nomenclature was the 1st level of Corine Land Cover programme which considers five categories of land-use: (i) artificial areas; (ii) agricultural areas; (iii) forest and semi-natural areas; (iv) wetlands; (v) water bodies (EEA, 2000). For both maps, a 2 hectare Minimum Mapping Unit (MMU) was defined with a $1: 5000$ work reference scale.

Thematic generalisation operations were carried out in which the areas with a MMU lower than 2 hectares were aggregated to the neighbouring land-use categories with a MMU greater or equal than 2 hectares. The land-use maps were converted from vector to raster data using a $10 \mathrm{~m}$ resolution. Figure 4 reveals an increase of the territory occupied by artificial areas between 1994 and 2005 due to urbanisation towards the agricultural areas.

Finally, a reclassification operation was carried out in which the urban class corresponded to the artificial areas and the non-urban class resulted from the aggregation of 


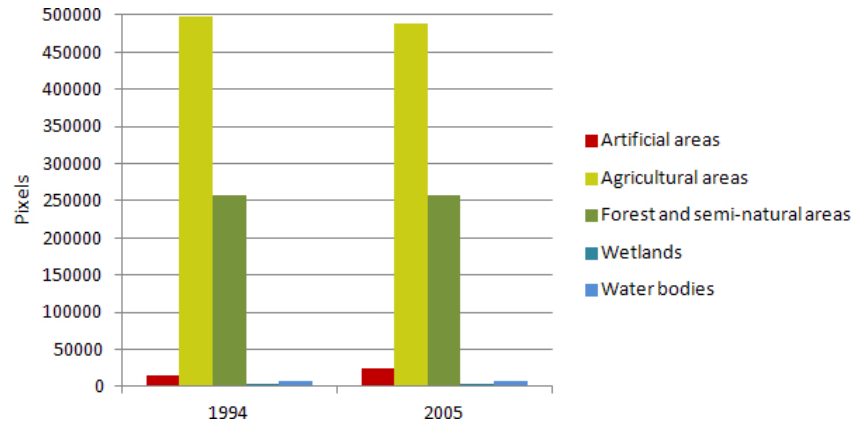

Fig. 4. Pixel sums of the Corine Land Cover classes for 1994 and 2005.

agricultural areas, forest and semi-natural areas, wetlands and water bodies. Two binary maps for 1994 and 2005 were produced (Fig. 5).

\subsection{Suitability map for urban areas}

This map defines the suitability of a cell changing from non-urban to urban class based on driving forces and exclusionary factors which can be obtained using MCA techniques (Voogd, 1983). In this case, a suitability map was created to incorporate expert knowledge based on a multistage group decision-making approach involving the authors of this study. This process was carried out in four stages and the result was used as an input of the model.

In the first stage, factors and constraints were identified. The driving forces incorporated in LUCC models are frequently related to socioeconomic and biophysical factors (Henríquez et al., 2006). Based on the potential behaviour of the local population towards land-use development, five factors were selected: (i) distance from roads (regional and municipal roads); (ii) topography (slope); (iii) distance from the 1st level urban centre (Ponta Delgada city); (iv) distance from 2nd level urban centres (Ribeira Grande and Lagoa villages); and (v) distance from the urban centre of Vila Franca do Campo (IGEOE, 1999). Two constraints restricted urban growth: (i) MMP and SCMP maps (Fig. 3); and (ii) the built areas of 1994, since urban growth cannot occur into previously built areas. We stress that the selection of factors and constraints reflects the basic constraints used for urbanisation in general and ignore the mitigation of geo-hazards.

The second stage comprised the factors standardisation. The integration and comparison of suitability factors is conditioned by the different measuring scales, making it imperative to standardise them on a common scale (Rashed and Weeks, 2003). Fuzzy Set Membership was employed to standardise the factors (Malczewski, 1999). It expresses the "relative degree of belonging to a set, ranging from 0.0 to 1.0 , indicating a continuous growth from not belonging up to total belonging" (Hansen, 2005, p. 78). Table 2 summarises the standardisation procedure.

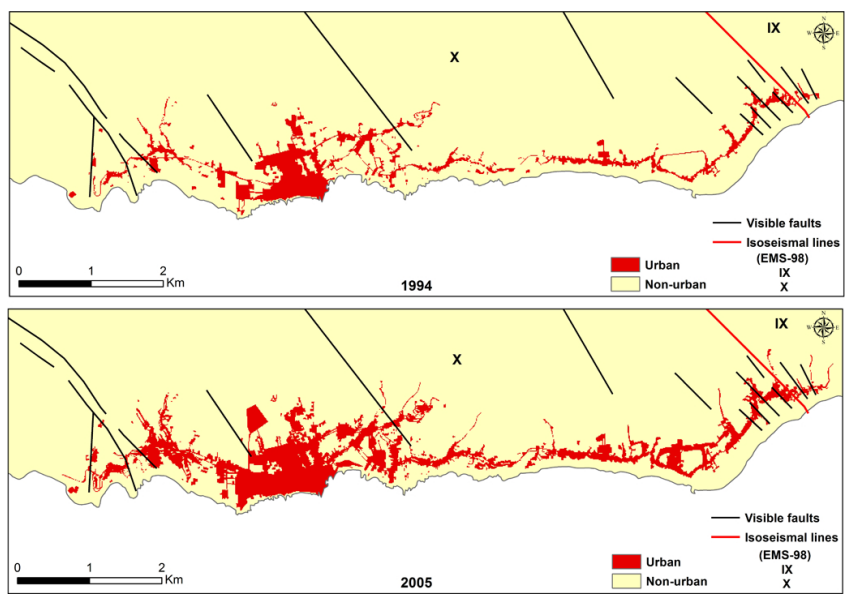

Fig. 5. Land-use maps of Vila Franca do Campo in 1994 and 2005.

During the third stage, the estimation of the factors weighting was carried out using the Analytical Hierarchy Process (AHP) method (Saaty, 1980). AHP is based on a comparison matrix to evaluate criteria according to the relative importance of the pairwise of factors being estimated (Eastman, 2006). The relative importance of each factor was defined based on the authors' knowledge about the study area regarding the demographic, socioeconomic and cultural dimensions (Martins et al., 2012). Results (Table 2) show that topography and distance from the urban centre of Vila Franca do Campo have the highest suitability weights (0.3523), followed by the distance from the 1 st level urban centre (0.1680). Distance from road networks $(0.0800)$ and distance from 2 nd level urban centres (0.0475) are the less important factors for suitability assessment. The consistency ratio which measures the consistency of the pairwise comparisons was 0.05 indicating a reasonable consistency level (Malczewski, 1999).

Decision rules is the final stage of the process, in which the suitability criterions are aggregated using Weighted Linear Combination (WLC). This method aggregates the factors by means of a weighted average (Eastman, 2006) which considers the criteria weights determined in the previous stage. According to Hansen (2005), the WLC Eq. (1) considers the suitability $S^{k}$ at the $k$-th pixel:

$S^{k}=\sum w_{i} x_{i}^{k}$

where $w_{i}$ is the weight and $x_{i}^{k}$ is the value of criterion $i$ in the $k$-th pixel (Hansen, 2005). The suitability is represented through a continuous scale of values, where 0 express the low suitability while 255 is assigned to high suitability values (Fig. 6).

\subsection{Urban modelling for year 2016 with Geomod}

Geomod (Pontius et al., 2001) is a LUCC model implemented by several authors to simulate land-use changes and 
Table 2. Standardisation procedures of the land-use change (non-urban to urban) driving factors and factors weights resulting from AHP.

\begin{tabular}{|c|c|c|c|c|}
\hline Factor & $\begin{array}{l}\text { Normalisation } \\
\text { function }\end{array}$ & $\begin{array}{l}\text { Control } \\
\text { points }\end{array}$ & Description & $\begin{array}{l}\text { Weights } \\
\text { (AHP) }\end{array}$ \\
\hline $\begin{array}{l}\text { Distance from road } \\
\text { network (1999) }\end{array}$ & Decreasing sigmoidal & $50-500 \mathrm{~m}$ & $\begin{array}{l}0-50 \text { mis the maximum suitability. It } \\
\text { decreases between } 50 \text { and } 500 \mathrm{~m} \text {. For } \\
\text { values higher than } 500 \text {, suitability is } \\
\text { minimal. }\end{array}$ & 0.0800 \\
\hline Topography (slopes) & Decreasing sigmoidal & 5-10 degrees & $\begin{array}{l}\text { Areas with slope between } 0 \text { to } 5 \text { degrees } \\
\text { have maximum suitability. Between } 5 \\
\text { and } 10 \text { degrees, the suitability decreases } \\
\text { sharply. For values higher than } 10 \text { de- } \\
\text { grees, suitability is minimal. }\end{array}$ & 0.3523 \\
\hline $\begin{array}{l}\text { Distance from the } 1 \text { st } \\
\text { level urban centre }\end{array}$ & Decreasing sigmoidal & $22-30 \mathrm{~km}$ & $\begin{array}{l}\text { Areas between } 0 \text { and } 22 \mathrm{~km} \text { from the } \\
\text { city of Ponta Delgada have the maxi- } \\
\text { mum suitability. It decreases between } \\
22 \text { and } 30 \mathrm{~km} \text { and it is minimal from } \\
30 \mathrm{~km} \text { onwards. }\end{array}$ & 0.1680 \\
\hline $\begin{array}{l}\text { Distance from 2nd level } \\
\text { urban centres }\end{array}$ & Decreasing sigmoidal & $10-14 \mathrm{~km}$ & $\begin{array}{l}\text { Areas between } 0 \text { and } 10 \mathrm{~km} \text { from } 2 \mathrm{nd} \\
\text { level urban centres have maximum suit- } \\
\text { ability. It slightly decreases between } 10 \\
\text { and } 14 \mathrm{~km} \text { and it is minimal from } 30 \mathrm{~km} \\
\text { onwards. }\end{array}$ & 0.0475 \\
\hline $\begin{array}{l}\text { Distance from the } \\
\text { urban centre of Vila } \\
\text { Franca do Campo }\end{array}$ & Decreasing sigmoidal & $2.5-6 \mathrm{~km}$ & $\begin{array}{l}\text { Areas between } 0 \text { and } 2,5 \mathrm{~km} \text { from the } \\
\text { urban centre of Vila Franca do Campo } \\
\text { have maximum suitability. Between } 2.5 \\
\text { and } 6 \mathrm{~km} \text {, suitability decreases. For val- } \\
\text { ues higher than } 6 \mathrm{~km} \text {, is minimal. }\end{array}$ & 0.3523 \\
\hline
\end{tabular}

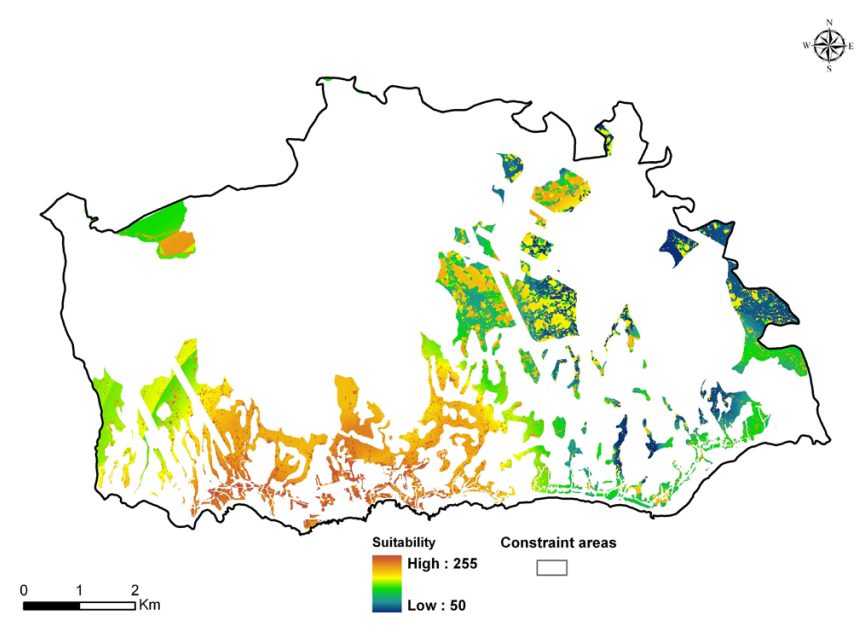

Fig. 6. Urban areas suitability map.

predict the expansion of urban areas (Pinto et al., 2009; Chen and Pontius, 2010). Geomod was the selected model to simulate urban growth between two categories (non-urban to urban) considering the MMP and SCMP regulations. Additionally, Geomod does not require a large amount of data to run which was a decisive feature due to the impossibility of mapping land-use in more than two time moments (1994 and 2005).

The modelling of Vila Franca do Campo urban expansion considers the 1994 land-use image as reference time 1, the 2005 year as the reference time 2, while the year 2016 (an equivalent time period to the one between 1994 and 2005) corresponds to simulated time 3 . The suitability map was used to locate the cells changing their state according to the transition rules, while a neighbourhood constraint search of $5 \times 5$ cells was employed for an $11 \mathrm{yr}$ time step. Geomod restricts the change of land-use state to cells that are on the edge between two categories of land-use assuming that the development of new areas can only succeed in previously developed areas.

After the previous stage of calibration, the assessment of the predictive power of LUCC models is developed through the verification of the "goodness-of-fit" of validation (Pontius et al., 2004; Pontius and Malanson, 2005). The validation of LUCC models predictive scenarios require a three-map comparison where the maps are reference time 1 , reference time 2, and simulation time 2. Validation comprehends the agreement (or error) resulting from the comparison between the simulation time 2 map and the reference (or real) time 2 map. In this case, quantity disagreement and allocation disagreement (Pontius and Millones, 2011) were the measures 


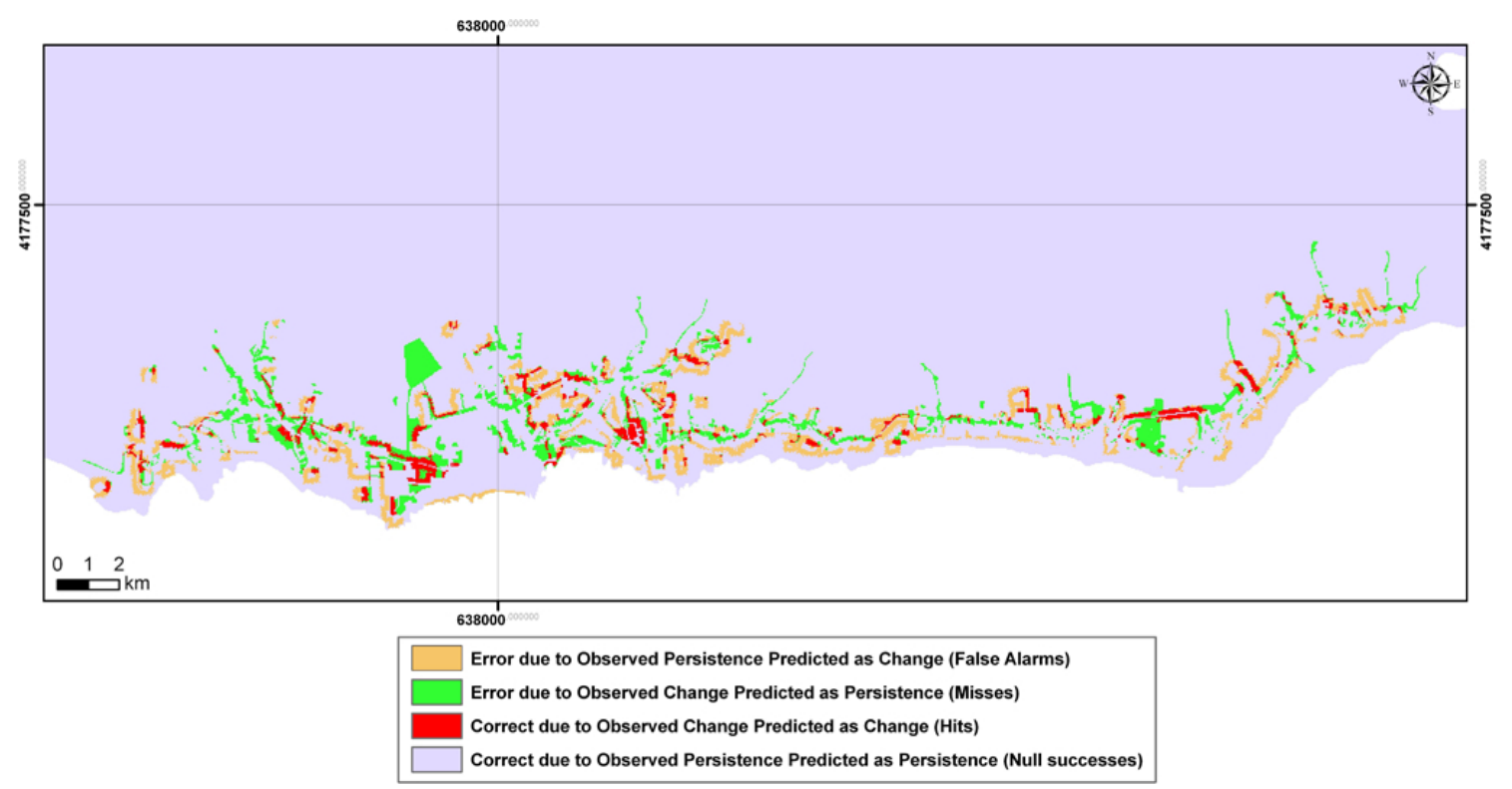

Fig. 7. Prediction correctness and error based on 1994 (reference), 2005 (reference) and 2005 (simulated) land-use maps.

used for assessing the accuracy of the model. The number of urban cells of the reference image of 2005 was used for modelling urban growth for year 2005, thus, there is not any disagreement due to quantity when comparing the model result for 2005 with the reference image of 2005.

Figure 7 shows the comparison of the observed change with the predicted change and distinguishes four types of correctness and error (Chen and Pontius, 2010): Correct due to Observed Persistence Predicted as Persistence (null successes), Error due to Observed Persistence Predicted as Change (false alarms), Correct due to Observed Change Predicted as Change (hits), Error due to Observed Change Predicted as Persistence (misses). This map was created using the predicted land cover map of 2005 which was overlaid with the reference map of 1994 to reflect persistence versus change. The percent of landscape that is hits correspond to $0.33 \%$ while the false alarms correspond to $0.83 \%$. There is only allocation error because we used the correct quantity $(2.5 \%)$. The total error $(2.5 \%)$ is greater than the observed change $(1.7 \%)$ so this model is less accurate than its null model, i.e., a model of no change.

The "figure of merit" is a ratio where the numerator is the number of hits and the denominator is the sum of hits, misses and false alarms. It ranges from $0 \%$, meaning no overlap between observed and predicted change, to $100 \%$, meaning perfect overlap between observed and predicted change (Pontius et al., 2011). In this case, the figure of merit was $17 \%$ which is a low performance, although higher than in some of the case studies presented in Pontius et al. (2008). The reasons for this performance may be explained by the small urbanised area between 1994 and 2005 (1.7\% of the total study area) and also by not having considered all the factors responsible for urban growth in the modelling process.

Finally, an urban growth scenario was modelled for the year 2016. This scenario assumes that urban growth tendency is the same as the one that was verified between 1994 and 2005, so the suitability map used was the same suitability map employed for modelling year 2005. The cells that are likely to change their state from non-urban to urban for year 2016 were obtained by linear extrapolation.

\section{Results}

In 1994, the urban areas represented 149.6 hectares of the territory while, in 2005, this value was 285 hectares. During 1994-2005, there was a significant urban growth in the surrounding areas of previously urbanised areas (Fig. 8). Urban growth occurred mainly in the areas defined as "urban perimeters" or "potentially urban areas" by the MMP (Fig. 9): 118.8 hectares (87.7\%) of the total of 135.4 hectares of urban growth (in the period 1994-2005) occurred within these areas, while the remaining 16.6 hectares $(12.3 \%)$ occurred outside (Fig. 8). On the other hand, regarding the urban expansion occurred outside the "urban perimeters" and "potentially urban areas" (Fig. 9), only 4.5 hectares (37.1\%) were located in areas where the urban growth is strictly restricted, while 12.1 hectares $(62.9 \%)$ were located in nonrestricted areas (Fig. 8). Although urban growth is residual inside the areas mapped as restricted by the MMP regulatory plans, it occurred in areas protected by RER regulations (Fig. 3a) which aim to protect natural resources and to avoid the urbanisation of hazardous places. Urban expansion has progressed towards the interior of the municipality and not 


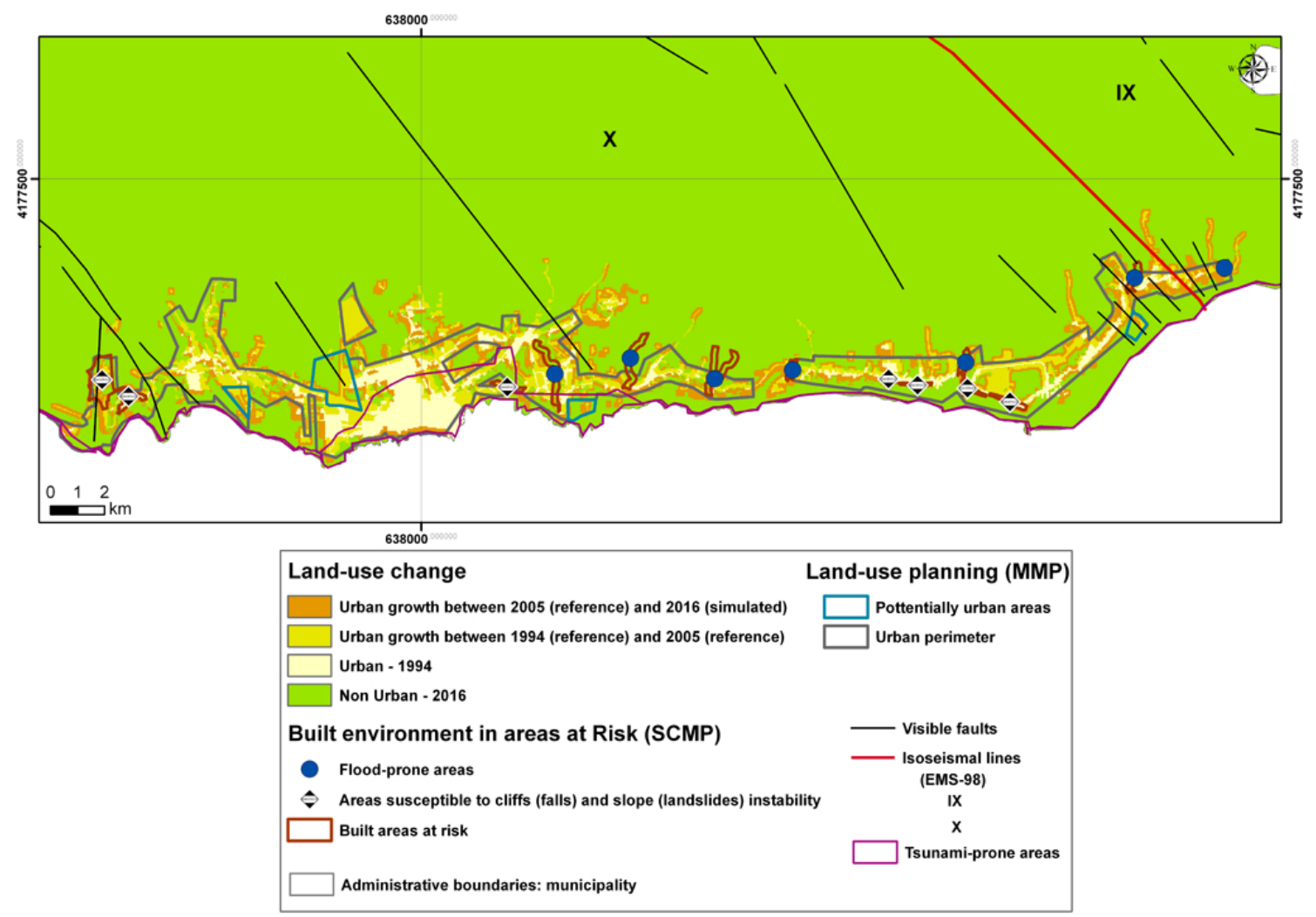

Fig. 8. Land-use change in Vila Franca do Campo, considering land-use plans and natural hazardousness. The figure shows the land-use use change in the period between 1994 and 2016, the land-use planning zonation elements, the areas built in hazardous areas and the seismic hazard elements.

along the coastline due to restrictions of the MMP, which define a buffer zone around the cliffs (Fig. 3a). We can establish, based on the previous remarks, that MMP regulatory plans (Fig. 3a) had a restraining effect on urban growth between 1994 and 2005 despite the slight urban growth inside the restricted areas defined by the MMP ( 4.5 hectares). This shows that the regulations of MMP (non mitigatory) were implemented.

Nevertheless, considering the elements that characterise seismic hazard in Vila Franca do Campo - geological faults and the isoseismal map (CMVFC, 1999) - it is possible to set some considerations regarding the success of MMP in mitigating seismic risk. In the 1994-2005 period, the urban expansion corresponded to a total area of 135.4 hectares, where 124 hectares $(91.6 \%)$ were located in the area limited by the X-grade isoseismal on EMS-98, while the remaining 11.4 hectares $(8.4 \%)$ were inside the area enclosed by the IX-grade isoseismal (Fig. 10). Between 1994 and 2005, urban growth occurred in areas with geological faults inside the urban perimeter (8 hectares), mainly in Água de Alto, Ponta Garça and to the $\mathrm{N}$ of the parish of S. Pedro (Fig. 10). This shows that the lack of hazard zoning (e.g., peak ground acceleration; fault lines; historical seismic activity maps) prevents the effectiveness of the 24th article of the MMP. In Fig. 8, it

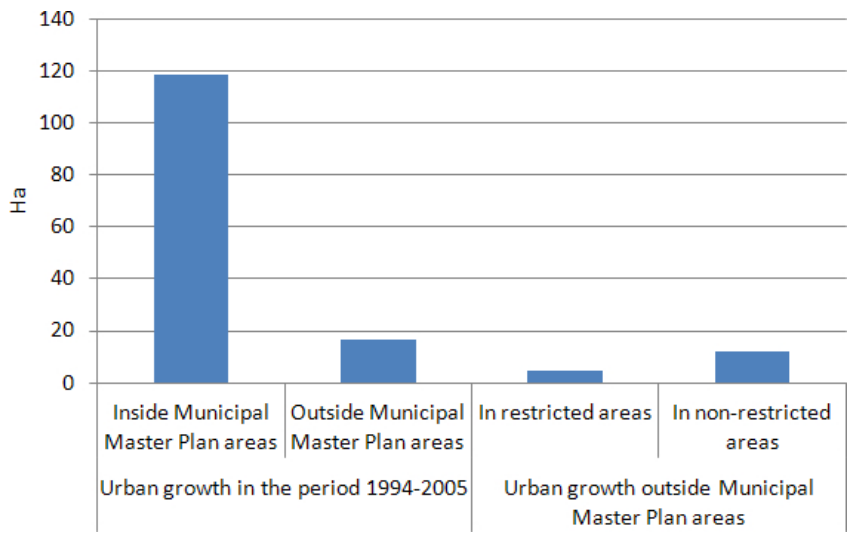

Fig. 9. Urban growth in the study area between 1994 and 2005 (hectares) considering the MMP jurisdiction areas.

is possible to identify vulnerable areas to tsunamis (CMVFC, 1999) where the areas of greatest exposure correspond to the main urban centres of the parishes of S. Miguel and S. Pedro (16 hectares).

In the period between 2005 (reference) and the scenario for 2016 (Fig. 8), the urban areas are predicted to represent 420 hectares. In this case, as verified in the period 


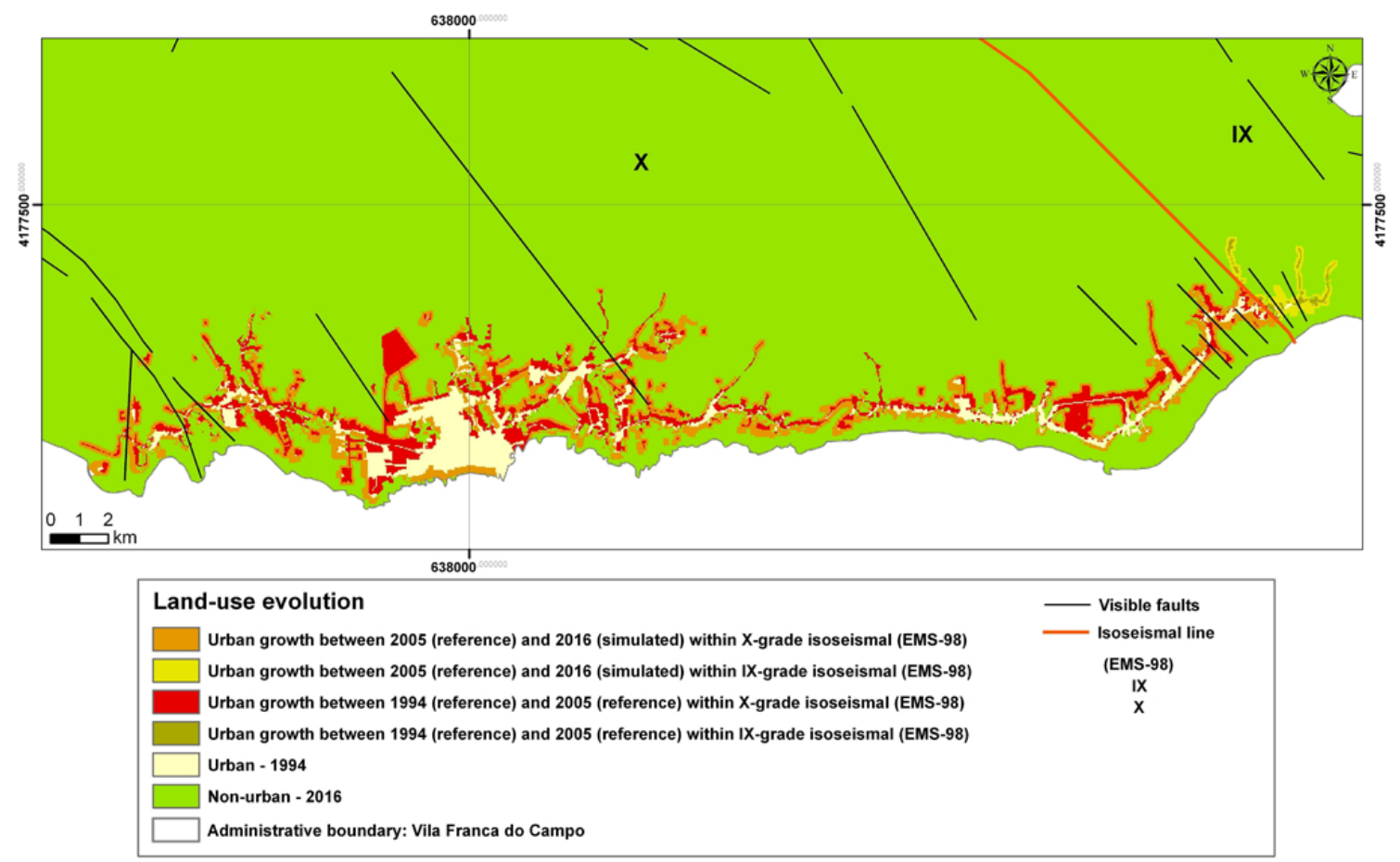

Fig. 10. Land-use change within the study area, taking into account the seismic hazard zonation, namely, isoseismal lines (EMS-98) and visible faults.

1994-2005, the development of new urban areas may occur within the "urban perimeters" and "potentially urban areas" of the MMP. It must be noted that these areas have the highest suitability values (Fig. 6). The scenario for 2016 suggests that the restrictive plans of MMP, and also the SCMP restrictions, will restrain urban growth (Fig. 3b). Nevertheless, the predictive scenario appears to confirm a continuous urban growth in the areas mainly classified as X-grade by the EMS-98 and also in the areas with geological faults (Fig. 10). It should be stressed that the areas classified by the SCMP as "Built Environment in Areas at Risk", where the flood-prone and cliff/slope instability areas are located, showed no urban growth for 2016 because they were used as a constraint in the model (Fig. 8). These areas had a minor urban growth between 1994 and 2005, when the SCMP was not in force.

\section{Conclusions}

This study draws important conclusions about the regulatory action of the land-use plans in Vila Franca do Campo regarding the urban development and their (in)efficiency in controlling this phenomenon according to seismic risk exposure.

Regarding the general restrictions (non mitigatory) of the MMP, the urban expansion was done according to the planning and development strategy outlined by the municipality during the period 1994-2005. Since the MMP was implemented and met with the general planning goals and urban development constraints, we conclude that it had a positive action in controlling urbanisation according to the established restrictive zoning regulations. The predicted scenario for 2016 reinforces this conclusion. On the other hand, considering the effect of mitigatory restrictions of the MMP (e.g., article 24) on urban growth, the MMP failed to promote the seismic risk reduction since it has occurred towards seismic prone areas in the period 1994-2005. Thus, the above positive seeming effects of the MMP are not comprehensive, since it does not couple land-use planning with seismic risk mitigation. We conclude that the planning process and land-use plan (MMP) were not structured towards seismic risk mitigation. These findings support the conclusions of the works from Calado et al. (2011) where it is stated that understanding the unique characteristics (e.g., population density; socioeconomic activities; natural hazardousness) of the Azores small islands is critical to establish the most appropriate land-use management policies, measures and actions.

Vila Franca do Campo is the municipality with the largest number of casualties due to earthquakes in the Azores Archipelago with a long record of earthquake-triggered disasters. Accordingly, the land-use planning process (and plans) must be more comprehensive towards seismic risk reduction (Martins et al., 2012). Thus, the construction of disaster resilient communities must be based in hazard mitigation and land-use planning, since it is the most capable ally to introduce mitigatory goals, policies and measures (Godschalck et al., 1998). This process must be supported by hazard zonation (Berke and Beatley, 1992). 
Geomod provided relevant spatio-temporal information about the urbanisation process and the possibility to understand the influence, effectiveness and efficiency of land-use plans on urban dynamics and seismic risk exposure. The low performance of the model, as indicated by the figure of merit $(17 \%)$, calls for future experimentations using other factors/constraints and/or modelling approaches. The scenario for 2016 is, as in any future scenario (Pontius et al., 2008), to be interpreted with caution.

Despite these limitations, the results are relevant for raising the awareness of policy makers, public officials and advocates of the need to include seismic risk mitigation policies in land-use plans. Establishing the relationship between urban expansion and seismic risk also allows measuring the potential impact of future disasters triggered by earthquakes. This can also be useful to support emergency management operational strategies. Future research will extend this methodology to all the Azores Archipelago.

Acknowledgements. The authors would like to thank the LusoAmerican Foundation (FLAD), which funded the project "Risk Governance: the case of seismic risk in Azores". We would also like to thank the reviewers for their useful comments that helped us improving this paper.

Edited by: A. Günther

Reviewed by: E. Koomen, R. G. Pontius, and

one anonymous referee

\section{References}

Berke, R. P. and Beatley, T.: Planning for earthquakes: risk, politics, and policy, The Johns Hopkins University Press, Baltimore, 1992.

Birkmann, J., Buckle, P., Jarger, J., Pelling, M., Setiadi, N., Garschagen, M., Fernando, F., and Kropp, J.: Extreme events and disasters: a window of opportunity for change? Analysis of organizational, institutional and political changes, formal and informal responses after mega-disasters, Nat. Hazards, 55, 637-655, doi:10.1007/s11069-008-9319-2, 2010.

Cabral, P.: Étude de la croissance urbaine par télédétection, SIG et modélisation: le cas des concelhos de Sintra et Cascais (Portugal), Ph.D. thesis, École des Autes Études en Sciences Sociales, Instituto Superior de Estatística e Gestão de Informação, 209 pp., 2006.

Calado, H., Borges, P., Phillips, Ng., K., and Alves, F.: The Azores archipelago, Portugal: improved understanding of small islands coastal hazards and mitigation measures, Nat. Hazards, 58, 427444, doi:1007/s11069-010-9676-5, 2011.

Chen, H. and Pontius, R.: Diagnostic tools to evaluate a spatial land change projection along a gradient of an explanatory variable, Landscape Ecol., 25, 1319-1331, doi:10.1007/s10980-0109519-5, 2010.

CMVFC: Câmara Municipal de Vila Franca do Campo: Plano director municipal de Vila Franca do Campo, Relatório da 2 fase, Volume 2 - Regulamento, Ponta Delgada, 1997.
CMVFC: Câmara Municipal de Vila Franca do Campo: Plano municipal de emergência do concelho de Vila Franca do Campo, ilha de S. Miguel, CVARG, Ponta Delgada, 1999.

CRED: Centre for Research on the Epidemiology of Disasters: Emergency events database, available at: http://www.emdat.be/ advanced-search (last access: 10 November 2010), 2010.

DROTRH/SRAM: Direcção Regional de Ordenamento do Território e Recursos Hídricos/Secretária Regional do Ambiente e do Mar: Plano de ordenamento da orla costeira da costa sul da ilha de S. Miguel, Relatório Síntese, Volume 5, Ponta Delgada, 2007.

Dynes, R. R.: Social science research on earthquake hazard mitigation: relevance for policy and practice, Preliminary Paper 163, Disaster Research Center, University of Delaware, Delaware, 1991.

Eastman, J. R.: IDRISI Andes: guide to GIS and image processing, Clark Labs, Clark University, Worcester, 2006.

EEA: European Environmental Agency: CORINE land cover technical guide - Addendum 2000, Technical Report no. 40, EEA, Copenhagen, 2000.

Godschalck, R. D. and Brower, D. J.: Mitigation strategies and integrated emergency management, Public Admin. Rev., 45, Special Issue: Emergency Management: A Challenge for Public Administration, 1985.

Godschalck, R. D., Kaiser, E. J., and Berke, P. R.: Integrating hazard mitigation and local use planning, in: Cooperating with nature: confronting natural hazards with land-use planning for sustainable communities, Joseph Henry Press, Washington DC, 1998.

Gomes, A., Gaspar, J. L., Goulart, C., and Queiroz, G.: Evaluation of landslide susceptibility of Sete Cidades Volcano (S. Miguel Island, Azores), Nat. Hazards Earth Syst. Sci., 5, 251257, doi:10.5194/nhess-5-251-2005, 2005.

Hansen, H. S.: GIS-based Multi-Criteria Analysis of wind farm development, in: Proceedings of the 10th Scandinavian Research Conference on Geographical Information Science, Stockholm, Sweden, 13-15 June 2005, 2005.

He, C., Okada, N., Zhang, Q., Shi, P., and Li, J.: Modelling a dynamic urban expansion processes incorporations a potential model with cellular automata, Landscape Urban Plan., 86, 7991, doi:10.1016/j.landurbplan.2007.12.010, 2008.

Henríquez, C., Azócar, G., and Romero, H.: Monitoring and modeling the urban growth of two mid-sized Chilean cities, Habitat Int., 30, 945-964, 2006.

Hewitt, K.: Regions of risk: a geographical introduction to disasters, Addison Wesley Longmann, Essex, 1997.

IGEOE: Instituto Geográfico do Exército: Carta Militar de Portugal - Açores (escala 1:25 000), no. 33 - Vila Franca do Campo (S. Miguel), Lisboa, 1999.

Koomen, E., Dekkers, J., and van Dijk, T.: Open-space preservation in the Netherlands: Planning, practice and prospects, Land Use Policy, 25, 361-377, doi:10.1016/j.landusepol.2007.09.004, 2008.

Malczewski, J.: GIS and Multicriteria Decision Analysis, John Wiley and Sons, New York, 1999.

Martins, V. N., Cabral, P., and Sousa e Silva, D.: Social vulnerability assessment to seismic risk using multicriteria analysis: the case study of Vila Franca do Campo (São Miguel Island, Azores, Portugal), Nat. Hazards, 62, 385-404, doi:10.1007/s11069-0120084-x, 2012. 
Oliver-Smith, A.: Theorizing vulnerability in a globalized world: a political ecological perspective, in: Mapping vulnerability: disasters, development, and people, Earthscan Publications Ltd., London, 2004.

Pinto, P., Cabral, P., Caetano, M., and Alves, F.: Urban growth on coastal erosion vulnerable stretches, J. Coastal Res., 2, 15671571, 2009.

Pontius, R. and Malanson, J.: Comparison of the structure and accuracy of two land change models, Int. J. Geogr. Inf. Sci., 19, 243-265, doi:10.1080/13658810410001713434, 2005.

Pontius, R. and Millones, M.: Death to Kappa: birth of quantity disagreement for accuracy assessment, Int. J. Remote Sens., 32, 4407-4429, doi:10.1080/01431161.2011.552923, 2011.

Pontius, R., Cornell, J., and Hall, C.: Modeling the spatial pattern of land-use change with GEOMOD2: application and validation for Costa Rica, Agr. Ecosyst. Environ., 1775, 1-13, doi:10.1016/S0167-8809(01)00183-9, 2001.

Pontius, R., Huffaker, D., and Denman, K.: Useful techniques of validation for spatially explicit land-change models, Ecol. Model., 179, 445-461, doi:10.1016/j.ecolmodel.2004.05.010, 2004.

Pontius, R., Boersma, W., Castella, J-C., Clarke, K., Nijs, T., Dietzel, C., Duan, Z., Fotsing, E., Goldstein, N., Kok, K., Koomen, E., Lippitt, D., McConnell, W., Sood, A. M., Pijanowski, B., Pithadia, S., Sweeney, S., Trung, T. N., Veldkamp, A. T., and Verburg, P. H.: Comparing the input, output, and validation maps for several models of land change, Ann. Reg. Sci., 42, 11-37, doi:10.1007/s00168-007-0138-2, 2008.

Pontius, R., Peethambaram, S., and Castella, J-C.: Comparison of three maps at multiple resolutions: a case study of land change simulation in Cho Don District, Vietnam, Ann. Assoc. Am. Geogr., 101, 45-62, 2011.
Rashed, T. and Weeks, J.: Assessing social vulnerability to earthquake hazards through spatial multicriteria analysis of urban areas, Int. J. Geogr. Inf. Sci., 17, 549-576, doi:10.1080/1365881031000114071, 2003.

Saaty, T. L.: The analytic hierarchy process: planning, priority setting, resource allocation, McGraw-Hill International Book Company, New York and London, 1980.

Silveira, D., Gaspar, J. L., Ferreira, T., and Queiroz, G.: Reassessment of the historical seismic activity with major impact on S. Miguel Island (Azores), Nat. Hazards Earth Syst. Sci., 3, 615623, doi:10.5194/nhess-3-615-2003, 2003.

SRCTE: Secretária Regional da Ciência, Tecnologia e Equipamentos: Ortofotomapas do concelho de Vila Franca do Campo, ilha de S. Miguel, Açores, Voos relativos aos anos de 1994 e 2005, Ponta Delgada, 2010.

SREA: Serviço Regional de Estatística dos Açores: Censos 2001, 2001.

UN/ISDR: United Nations International Strategy for Disaster Reduction: Living with risk. A global review of disaster reduction initiatives, United Nations, Geneva, 2004.

Valadão, P., Gaspar, J. L., Queiroz, G., and Ferreira, T.: Landslides density map of S. Miguel Island, Azores archipelago, Nat. Hazards Earth Syst. Sci., 2, 51-56, doi:10.5194/nhess-2-51-2002, 2002.

Verburg, P. H., de Koning, G. H. J., Kok, K., Veldkamp, A., and Bouma, J.: A spatial explicit allocation procedure for modelling the pattern of land use change based upon actual land use, Ecol. Model., 116, 45-61, doi:10.1016/S0304-3800(98)00156-2, 1999.

Voogd, H.: Multicriteria Evaluation for Urban and Regional Planning, Pion Limited, London, 1983. 